Pendas: Primary Education Journal

Volume 2 Nomor 1, Januari - Juni 2021

P-ISSN: 2686-5130 || E-ISSN : 2776-298X

Availabel online at: https://journal.unram.ac.id/index.php/pendas

\title{
HUBUNGAN ANTARA PENDIDIKAN KARAKTER DENGAN KECERDASAN SOSIAL SISWA KELAS V SDN GUGUS V KECAMATAN CAKRANEGARA
}

\author{
Bq Weddayu Murferatiwi ${ }^{1 *}$, Darmiany ${ }^{2)}$, Khairun Nisa ${ }^{3)}$ \\ ${ }^{1,2,3)}$ Pendidikan Guru Sekolah Dasar, FKIP - Universitas Mataram \\ *Corresponding Author: Wedda.yu@gmail.com
}

\begin{tabular}{|c|c|}
\hline ARTICLE INFO & ABSTRACT \\
\hline 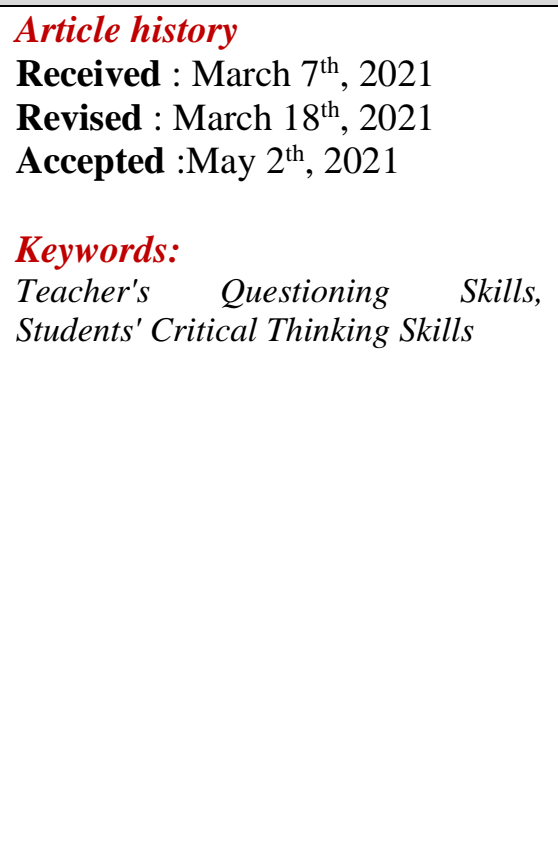 & $\begin{array}{l}\text { Learning in the } 21 \text { st century must be able to develop competitive skills } \\
\text { that focus on developing higher order thinking skills, one of which is } \\
\text { critical thinking. Therefore we need a basic teaching skill of teachers } \\
\text { in order to develop the quality of learning one of which is the teacher } \\
\text { asking questions. This study aims to determine whether there is a } \\
\text { relationship between the teacher's questioning skills and the critical } \\
\text { thinking skills of class V students of Cakranegara group } 32018 / 2019 \\
\text { academic year. This research uses a quantitative approach with a } \\
\text { descriptive correlational type. The subjects in this study were fifth } \\
\text { grade students in Cluster III Cakranegara with a population of } 130 \\
\text { students. Samples were taken randomly using a simple random } \\
\text { sampling type probability sampling technique to obtain } 65 \text { students. } \\
\text { Data collection techniques used were questionnaire and multiple } \\
\text { choice tests. While the data analysis technique is the Pearson product } \\
\text { moment correlation by using the SPSS } 16.0 \text { program. Based on the } \\
\text { results of data analysis, it was found that the value of sig (2-tailed) } \\
0.00<0.05 \text {, which means it can be said to be significant and there is a } \\
\text { relationship between the teacher's questioning skills and students' } \\
\text { critical thinking skills. Based on this research, principals and teachers } \\
\text { need to support and develop students' critical thinking skills through } \\
\text { the teacher's questioning skills well. }\end{array}$ \\
\hline
\end{tabular}

ABSTRAK. Pembelajaran pada abad ke-21 harus mampu mengembangkan keterampilan kompetitif yang berfokus pada pengembangan keterampilan berfikir tingkat tinggi (higher order thinking skills) yang mana salah satunya adalah berfikir kritis (critical thinking). Oleh karena itu diperlukan suatu keterampilan dasar mengajar guru dalam rangka mengembangkan mutu pembelajaran salah satunya adalah keterampilan bertanya guru. Penelitian ini bertujuan untuk mengetahui apakah ada hubungan antara keterampilan bertanya guru dengan kemampuan berfikir kritis siswa kelas V gugus 3 Cakranegara tahun pembelajaran 2018/2019. Penelitian ini menggunakan pendekatan kuantitatif dengan jenis deskriptif korelasional. Subyek dalam penelitian ini adalah siswa kelas V di Gugus III Cakranegara dengan jumlah populasi 130 siswa. Sampel diambil secara acak dengan menggunakan teknik probability sampling tipe simple random sampling sehingga diperoleh 65 siswa. Teknik pengumpulan data yang digunakan yakni angket dan tes pilihan ganda. Sedangkan teknik analisis data adalah correlasi product moment dari Pearson dengan menggunakan program SPSS 16.0. Berdasarkan hasil analisis data diperoleh bahwa nilai sig (2tailed) $0,00<0,05$ yang artinya dapat dikatakan signifikan dan ada hubungan antara keterampilan bertanya guru dengan kemampuan berfikir kritis siswa. Berdasarkan penelitian tersebut kepala sekolah 


\section{A. PENDAHULUAN}

Di era globalisasi seperti sekarang sangatlah mudah seseorang mendapatkan informasi. Seseorang harus bisa menganalisa asumsi-asumsi ataupun pendapat yang melandasinya secara logis dan meyakinkan pendapatnya kepada orang lain, untuk melakukan hal demikian seseorang harus memiliki suatu kompetensi berfikir kritis (Afianti et al., 2020).

Telah ditetapkan standar kompetensi lulusan yang berbasis pada kompetensi abad XXI, bahwa pembelajar pada abad ke-21 harus mampu mengembangkan keterampilan kompetitif yang berfokus pada pengembangan keterampilan berfikir tingkat tinggi (higher order thinking skills) yang mana salah satunya adalah berfikir kritis (critical thinking).

Oleh karena itu, tugas guru adalah menciptakan peluang bagi siswa untuk mengembangkan dan meningkatkan keterampilan berfikir kritis, karena siswa dengan keterampilan berfikir kritis mampu memahami dunia di sekitarnya, membuat keputusan yang baik, meningkatkan kinerja, dan meningkatkan motivasi belajarnya.

Menurut Suprijono (2016), berfikir kritis adalah proses mengaplikasikan, menghubungkan, menciptakan, atau mengevaluasi informasi yang dikumpulkan secara aktif dan terampil. Siswono (2008), berpendapat bahwa, berfikir kritis termasuk salah satu perwujudan berfikir tingkat tinggi (high order thingking).

Keterampilan berfikir kritis dapat dikembangkan atau diperkuat, melalui proses pembelajaran. Pertanyaan-pertanyaan tingkat-tinggi (high-level question) dapat mendorong pemikiran kritis dan lebih mendalam melalui penerapan lima tingkatan proses dalam ranah kognitif (Jacobsen dkk, 2009).

Tim Penyusun Panduan Pengajaran Mikro (2014), menyatakan bahwa keterampilan bertanya adalah cara guru menyampaikan pertanyaan kepada siswa dalam pembelajaran, baik pertanyaan dasar maupun pertanyaan lanjut. Kita menggunakan strategi-strategi questioning di dalam kelas untuk membantu siswa mempelajari konten dan untuk mengajari mereka berfikir lebih kritis dan analitis (Jacobsen dkk, 2009).

Tujuan penelitian ini adalah untuk mengetahui Bagaimana gambaran keterampilan bertanya guru dengan kemampuan berfikir kritis siswa dan apakah ada hubungan antara keterampilan bertanya guru dengan kemampuan berfikir kritis siswa kelas $\mathrm{V}$ gugus 3 Cakranegara tahun pembelajaran 2018/2019.

Hasil penelitian Ahmatika (2016), yang berjudul "Peningkatan Kemampuan Berfikir Kritis Siswa dengan Pendekatan Inquiry/Discovery”, diperoleh kesimpulan bahwa terdapat peningkatan kemampuan berpikir kritis siswa dengan pendekatan inquiry/discovery dalam pembelajaran matematika. Perbedaan penelitian ini dengan penelitian sebelumnya yakni penelitian ini menggunakan pendekatan PTK (penelitian tindakan kelas) dengan metode penelitian menggunakan kuasi eksperimen sehingga metode analisis data menggunakan uji normalitas, homogenitas, dan uji hipotesis menggunakan rumus uji-t yang berfungsi untuk mengetahui perbandingan antara metode improve dengan metode konvensional.

Kemudian hasil penelitian yang dilakukan oleh Prasetyaningrum (2014), dalam penelitiannya berjudul "Pengaruh Keterampilan Bertanya Guru terhadap Kemampuan Berfikir 
Kritis Anak Kelompok B di TK Al-Hidayah", simpulan penelitian menunjukkan bahwa keterampilan bertanya guru berpengaruh positif terhadap kemampuan berpikir kritis pada anak kelompok B di TK Al-Hidayah Pakis Tirtosari Surabaya. Perbedaan penelitian ini dengan penelitian sebelumnya adalah pendekatan kuantitatif dengan jenis pre-experimental designs dengan menggunakan tipe one group pretest-posttest design. Subyek penelitian berjumlah 22 anak. Analisis data menggunakan statistik non parametris dengan rumus Sign Test dimana jika taraf kesalahan > p tabel maka Ho ditolak dan Ha diterima.

\section{B. METODE PENELITIAN}

Jenis penelitian ini adalah penelitian deskriptif korelasional dengan menggunakan pendekatan kuantitatif, yakni metode penelitian yang berlandaskan pada filsafat positivisme, digunakan untuk meneliti pada populasi atau sampel tertentu, pengumpulan data menggunakan instrumen penelitian, analisis data bersifat kuantitatif/statistik, dengan tujuan untuk menguji hipotesis yang telah ditetapkan (Sugiyono, 2017).

Menurut Sugiyono (2012) "Penelitian asosiatif atau hubungan adalah penelitian yang bertujuan untuk mengetahui hubungan antara dua variabel atau lebih. Penelitian ini mempunyai tingkatan yang lebih tinggi bila dibandingkan dengan penelitian deskriptif dan komparatif'. Karena penelitian bertujuan untuk mengetahui hubungan antara dua variabel.

Rancangan penelitian korelasional untuk mengukur hubungan antara dua atau lebih variabel. Skala pengukuran data interval menggunakan uji statisitik parametrik. Berikut ini paradigma sederhana yang ditunjukkan pada gambar 3.1.

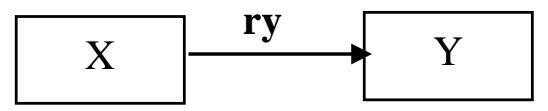

Waktu penelitian dilaksanakan pada tanggal 18-24 Mei 2019 pada pukul 08.00 WITA ini akan dilaksanakan dalam waktu 7 hari. Tempat penelitian dilaksanakan di SDN Gugus 3 Cakranegara yang terdiri dari 4 sekolah yakni; SDN 02 Cakranegara, SDN 21 Cakranegara, SDK Antonius, dan SDN Model Mataram. Populasi dalam penelitian ini secara ringkas ditunjukkan pada tabel 1 berikut ini.

Tabel 1. Populasi Siswa Kelas V SDN Gugus 03 Kecamatan Cakranegara

\begin{tabular}{ccccc}
\hline \multirow{2}{*}{ No } & \multirow{2}{*}{ Nama Sekolah } & \multicolumn{2}{c}{$\begin{array}{c}\text { Jumlah Siswa Kelas V } \\
\text { berdasarkan Jenis Kelamin }\end{array}$} & \multirow{2}{*}{ Jumlah } \\
\cline { 3 - 4 } & & $\mathrm{L}$ & $\mathrm{P}$ & \\
\cline { 3 - 4 } 1. & SD 02 Cakranegara & 20 & 20 & 40 \\
\hline 2. & SD 21 Cakranegara & 22 & 14 & 36 \\
\hline 3. & SDK Antonius & 10 & 14 & 24 \\
\hline 4. & SD Model Mataram & 18 & 12 & 30 \\
\hline \multicolumn{4}{c}{ Total } \\
\hline
\end{tabular}

Untuk menetapkan sampel menurut Arikunto (2006), bahwa jika jumlah subyek lebih dari 100, dapat diambil sampel 10\%-15\% dan 20-25\%, atau lebih. Sampel diambil secara acak dari 4 SD di Gugus 3 Cakranegara dengan menggunakan teknik probability sampling tipe simple random sampling. Sugiyono (2017), dikatakan simple (sederhana) karena pengambilan anggota sampel dan populasi dilakukan secara acak tanpa memperhatikan strata yang ada dalam populasi itu. Berdasarkan pendapat Arikunto tersebut maka penentuan sampel dalam penelitian ini menggunakan persentase $50 \%$. Dengan populasi 130 siswa maka diambil sampel 65 siswa. 
Tabel 2. Sampel Siwa Kelas V Gugus 3 Kecamatan Cakranegara

\begin{tabular}{lcc}
\multicolumn{1}{c}{ Nama sekolah } & Populasi & Sampel \\
\hline SD 02 Cakranegara & 40 & 20 \\
\hline SD 21 Cakranegara & 36 & 18 \\
\hline SDK Antonius & 24 & 12 \\
\hline SD Model Mataram & 30 & 15 \\
\hline \multicolumn{1}{c}{ Jumlah } & & 65
\end{tabular}

Dalam pelaksanaan penelitian jenis data yang dapat dikumpulkan peneliti yakni: Data kuantitatif (nilai hasil belajar siswa) yang dapat dianalisis secara deskriptif. Dalam hal ini peneliti menggunakan analisis statistik deskriptif. Misalnya, mencari nilai rerata, persentase keberhasilan belajar, dan lain-lain (Arikunto dkk, 2014). Sedangkan metode pengumpulan data dalam penelitian ini yakni sebagai berikut:

1. Kuisioner (angket) memiliki 25 pernyataan yang terdiri dari 14 pernyataan positif dan 11 pernyataan negatif. Teknik pengukuran angket ini dihitung dengan skala Guttman, yaitu skala yang digunakan untuk jawaban bersifat jelas (tegas) yaitu "Ya atau "Tidak".

2. Tes tulis yang mencakup 5 bidang studi soal pengetahuan umum yakni terdiri dari muatan PPKn, IPA, Matematika, Bahasa Indonesia, dan IPS. Masing-masing muatan terdiri dari 45 pertanyaan sehingga total seluruh pertanyaan adalah 20 soal dengan pilihan jawaban A,B,C,D.

Sebelum angket dan tes pilihan ganda digunakan untuk mengumpulkan data, terlebih dahulu dilakukan uji coba instrumen untuk mengetahui kelayakan instrument untuk dijadikan instrumen penelitian, maka perlu diadakan uji validitas dari ahli (judgment experts).

Untuk mengetahui uji statistik yang akan digunakan dalam penelitian ini, maka perlu dilakukan uji asumsi klasik yaitu uji normalitas dan linearitas. Setelah diketahui bahwa data berdistribusi normal dan linearitas, setelah itu maka dilakukan uji hipotesis dengan menggunakan uji statistik parametrik. Adapun tujuan uji hipotesis yaitu untuk menemukan suatu kesimpulan apakah hipotesis diterima atau ditolak. Uji hipotesis yang digunakan dalam penelitian ini korelasi product moment dari Pearson dengan menggunakan program SPSS 16.0 for windows yang bertujuan untuk mengetahui apakah ada hubungan antara keterampilan bertanya guru dengan kemampuan berfikir kritis siswa dengan ketentuan:

Jika nilai sig.(2-tailed) pada kolom value $<0,05$ maka dapat dikatakan signifikan dan ada hubungan antara keterampilan bertanya guru dengan kemampuan berfikir kritis siswa. Jika nilai sig.(2-tailed) pada kolom value $>0,05$ maka dapat dikatakan tidak signifikan dan tidak ada hubungan antara keterampilan bertanya guru dengan kemampuan berfikir kritis siswa.

Berikut ini adalah rumus korelasi product moment dari Pearson:

$$
\text { rhitung }=\frac{N \sum X Y-\left(\sum X\right)\left(\sum Y\right)}{\sqrt{\left\{N \sum X^{2}-\left(\sum X\right)^{2}\right\}\left\{N \sum Y^{2}-\left(\sum \mathrm{Y}\right)^{2}\right\}}}
$$

Sumber: Arifin (2017)

\section{HASIL DAN PEMBAHASAN}

\section{Hasil penelitian}

\subsection{Uji Validitas Instrumen}

Instrument angket dan soal pilihan ganda telah diuji kepada ahli atau dosen untuk diuji apakah agket dan soal tersebut dinyatakan layak untuk dijadikan instrumen dalam penelitian 
atau tidak. Hasil diskusi instrument dengan Dosen ahli yakni ada beberapa perbaikan untuk kisi-kisi dan kesesuaian butir item dengan kisi-kisi, pemilihan kata, isi atau muatan materi, dan tujuan yang ingin dicapai. Instrument ini tidak perlu melakukan uji lapangan karena telah melakukan uji ahli di 2 dosen yang berbeda yakni melalui Drs. I. Ketut Widiada, M.Pd dan Bapak Heri Setiawan, M.Pd

\subsection{Uji Normalitas}

Dengan bantuan SPSS 16.0 diperoleh output hasil uji normalitas data keterampilan bertanya guru dengan kemampuan berfikir kritis siswa. Adapun ringkasan hasil analisa dapat disajikan pada tabel berikut.

Tabel 3. Hasil Uji Normalitas Varians Data Keterampilan Bertanya Guru dan Kemampuan Berfikir Kritis Siswa di Gugus III Cakranegara

One-Sample Kolmogorov-Smirnov Test

\begin{tabular}{ll|r|r|}
\hline & & $\begin{array}{c}\text { Keterampil } \\
\text { anBertanya } \\
\text { Guru }\end{array}$ & $\begin{array}{c}\text { KemampuanB } \\
\text { erfikirKritisSis } \\
\text { wa }\end{array}$ \\
\hline $\mathrm{N}$ & 65 & 65 \\
Normal & Mean & 81.48 & 76.23 \\
Parameters & Std. & 10.644 & 15.911 \\
& Deviation & .161 & .131 \\
Most Extreme & Absolute & .161 & .104 \\
Differences & Positive & -.150 & -.131 \\
& Negative & 1.301 & 1.054 \\
Kolmogorov-Smirnov Z & .068 & .217 \\
Asymp. Sig. (2-tailed) & & \\
\hline a. Test distribution is & & \\
Normal. & &
\end{tabular}

Pada tabel diperoleh taraf signifikan data keterampilan bertanya guru 0,068 artinya data tersebut berdistribusi normal. Dengan mengambil kesimpulan jika sig $>0,05$ maka data normal dan jika sig < 0,05 maka data tidak normal. Sedangkan data kemampuan berfikir kritis siswa memiliki taraf signifikan 0,217 artinya data tersebut juga berdistribusi normal. Dengan kesimpulan 0,217>0,05, maka data berdistibusi normal.

\subsection{Uji Linearitas}

Jika nilai signifikansi $>0,05$ pada taraf signifikansi 5\% maka data memiliki hubungan yang linear. Jika nilai signifikansi $<0,05$ pada taraf signifikansi 5\% maka data memiliki hubungan yang tidak linear. Adapun ringkasan hasil analisis tersebut sebagai berikut.

Tabel 4. Hasil Uji Linearitas pada Keterampilan Bertanya Guru dan Kemampuan Berfikir Kritis Siswa di Gugus III Cakranegara 


\begin{tabular}{|c|c|c|c|c|c|c|}
\hline \multicolumn{7}{|c|}{ ANOVA Table } \\
\hline & & $\begin{array}{c}\text { Sum of } \\
\text { Squares }\end{array}$ & df & $\begin{array}{l}\text { Mean } \\
\text { Square }\end{array}$ & $F$ & Sig. \\
\hline $\begin{array}{l}\text { Kemamp } \\
\text { uanBerfik } \\
\text { irKritisSis } \\
\text { wa * } \\
\text { Keteramp u } \\
\text { ilanBerta } \\
\text { nyaGuru }\end{array}$ & $\begin{array}{l}\text { Bet (Combine } \\
\text { wee d) } \\
n \\
\text { Gro Linearity } \\
\text { ups } \\
\\
\quad \begin{array}{l}\text { Deviation } \\
\text { from } \\
\text { Linearity }\end{array} \\
\text { Within Groups } \\
\text { Total }\end{array}$ & $\begin{array}{r}5061.538 \\
3965.316 \\
1096.223 \\
11140.000 \\
16201.538\end{array}$ & $\begin{array}{r}6 \\
57 \\
64\end{array}$ & $\begin{array}{c}723.077 \\
3965.316 \\
182.704 \\
195.439\end{array}$ & $\begin{array}{c}3.700 \\
20.289\end{array}$ & $\begin{array}{l}.002 \\
.000\end{array}$ \\
\hline
\end{tabular}

Dari tabel di atas dapat diketahui nilai signifikansi yaitu 0,477>0,05 yang artinya terdapat hubungan yang linear secara signifikan antara variabel keterampilan bertanya guru dengan kemampuan berfikir kritis siswa. Sehingga dapat disimpulkan data berdistribusi linear.

\subsection{Pengujian Hipotesis}

Berikut ini ringkasan hasil analisis ditujukkan pada tabel di bawah ini.

Tabel 4. Hasil Uji Hipotesis pada Keterampilan Bertanya Guru dengan Kemampuan

Berfikir Kritis Siswa di Gugus III Cakranegara

\section{Correlations}

\begin{tabular}{|c|c|c|c|}
\hline & & $\begin{array}{c}\text { Keterampil } \\
\text { anBertanya } \\
\text { Guru }\end{array}$ & $\begin{array}{c}\text { Kemampuan } \\
\text { BerfikirKritis } \\
\text { Siswa }\end{array}$ \\
\hline \multirow{2}{*}{\multicolumn{2}{|c|}{$\begin{array}{|ll|}\text { Keterampil } & \text { Pearson } \\
\text { anBertanya } & \text { Correlation } \\
\text { Guru } & \text { Cin }\end{array}$}} & \multirow[t]{2}{*}{1} & \multirow{3}{*}{$\begin{array}{r}.495^{\star} \\
.000 \\
65\end{array}$} \\
\hline & Sig. (2-tailed) & & \\
\hline & $\mathrm{N}$ & 65 & \\
\hline \multicolumn{2}{|c|}{$\begin{array}{l}\text { Kemampua Pearson } \\
\text { nBerfikirKrit Correlation }\end{array}$} & & 1 \\
\hline isSiswa & Sig. (2-tailed) & .000 & \\
\hline & $\mathrm{N}$ & 65 & 65 \\
\hline
\end{tabular}

Dari tabel di atas dapat diketahui nilai signifikan (2-tailed) $0,00<0,05$ yang artinya dapat dikatakan signifikan dan ada hubungan antara keterampilan bertanya guru dengan kemampuan berfikir kritis siswa. Selain itu, analisis yang digunakan untuk menguji hipotesis penelitian ini yakni menggunakan corelasi product moment dengan membuat tabel penolong melalui program aplikasi Mic Excel, hipotesis nihil $\left(\mathrm{H}_{\mathrm{O}}\right)$ akan ditolak dan hipotesis alternatif $\left(\mathrm{H}_{\mathrm{a}}\right)$ akan diterima jika $\mathrm{r}_{\text {hitung }} \geq \mathrm{r}_{\text {tabel }}$. Dalam penelitian ini $\mathrm{r}_{\text {tabel }}$ ditentukan menggunakan corelasi product moment dengan taraf signifikasi $5 \%$. Adapun $r_{\text {tabel }}$ penelitian ini adalah 0,24 dan $r_{\text {hitung }}$ yang diperoleh adalah 0,49 . Sehingga nilai hipotesis dalam penelitian ini adalah $0,49>0,24$, dapat disimpulkan bahwa ada hubungan antara keterampilan bertanya guru dengan kemampuan berfikir kritis siswa kelas V SDN Gugus III Cakranegara tahun pembelajaran 2018/2019. 


\section{Pembahasan}

Penelitian ini dilakukan untuk mengetahui hubungan antara keterampilan bertanya guru dengan kemampuan berfikir kritis siswa kelas V SDN Gugus III Cakranegara tahun pembelajaran 2018/2019. Sebelum instrument diberikan kepada siswa saat penelitian, maka terlebih dahulu instrument tersebut diuji oleh Dosen ahli. Ada beberapa revisi oleh Dosen ahli salah satunya yakni kisi-kisi keterampilan bertanya guru dan lembar angket, Beliau menyarankan untuk menggunakan kata-kata yang lebih konkrit dan disesuaikan dengan kebutuhan siswa. Bahasa yang digunakan pada lembar angket siswa masih bersifat abstrak seperti menggunakan kata siswa seharusnya menggunakan kata saya, hal ini sesuai dengan pendapat dari Rousseau (Crain, 2007), bahwa masa kanak-kanak awal (usia dua sampai dua belas tahun) belum mampu memahami hal-hal yang bersifat abstrak.

Untuk instrument berfikir kritis yakni soal pilihan ganda, ada beberapa revisi dari Dosen ahli salah satunya adalah isi soal harus menggambarkan indikator berfikir kritis dilihat dari segi bahasan, materi, dan kata tanya konkrit sesuai dengan tingkatan kognitif pertanyaan. Jumlah siswa yang berada di kelas V Gugus III adalah 40 siswa dari SDN 02 Cakranegara, 36 siswa dari SDN 21 Cakranegara, 24 siswa dari SDK Antonius, dan 30 siswa SDN Model Mataram. Sehingga total semua populasi yang berada di Gugus III adalah 130 siswa. Penentuan sampel dalam penelitian ini menggunakan persentase 50\%. Dengan populasi 130 siswa maka diambil sampel 65 siswa. Pengambilan sampel tersebut diambil secara random atau acak dimana setiap siswa mempunyai kesempatan yang sama, misalnya dengan memilih siswa berdasarkan no absen dan berdasarkan tempat duduk.

Teknik pengumpulan data yang digunakan dalam penelitian ini yaitu angket dan tes tulis pilihan ganda. Peneliti melakukan uji expert kepada dua dosen ahli dengan melakukan konsultasi dan revisi pada angket, dari hasil tersebut diperoleh 25 pernyataan yang terdiri dari 14 pernyataan positif dan 11 pernyataan negatif. Sedangkan instrument berfikir kritis menggunakan tes tulis pilihan ganda yang terdiri dari 5 bidang studi dengan tingkat kognitif $\mathrm{C}_{4}, \mathrm{C}_{5}, \mathrm{C}_{6}$. Kemampuan berfikir kritis ini merujuk pada indikator menurut Krathwohl (2002), yakni lebih memfokuskan pada tahap menganalisis, mengevaluasi, dan menciptakan. Untuk mengetahui data keterampilan bertanya guru dengan kemampuan berfikir kritis siswa tersebut berdistribusi normal atau tidak maka peneliti menggunakan uji normalitas dengan teknik Kolmogrov-Smirnov. Hasil analisis diperoleh masing-masing data keterampilan bertanya guru sebesar 0,068 dan kemampuan berfikir kritis siswa sebesar 0,217 yang artinya kedua data tersebut berdistribusi normal.

Uji linear ini menggunakan teknik anova, adapun ringkasan dari hasil analisis tersebut sebagai berikut: Hasil nilai signifikansi hitung dari tabel 4.2 adalah 0,477>0,05, sehingga dapat disimpulkan terdapat hubungan linear secara signifikan antara keterampilan bertanya guru dengan kemampuan berfikir kritis siswa.

Sedangkan uji hipotesis peneliti menggunakan rumus correlasi product moment dari Pearson dengan menggunakan program SPSS 16.0, dari tabel 4.3 dapat diketahui nilai signifikan (2-tailed) 0,00<0,05 yang artinya dapat dikatakan signifikan dan ada hubungan antara keterampilan bertanya guru dengan kemampuan berfikir kritis siswa. Selain itu, analisis yang digunakan untuk menguji hipotesis penelitian ini yakni menggunakan correlasi product moment dengan membuat tabel penolong melalui program aplikasi Mic Excel, hipotesis nihil (Ho) akan ditolak dan hipotesis alternatif $\left(\mathrm{H}_{\mathrm{a}}\right)$ akan diterima jika $\mathrm{r}_{\text {hitung }} \geq \mathrm{r}_{\text {tabel }}$. Dalam penelitian 
ini $\mathrm{r}_{\text {tabel }}$ ditentukan menggunakan correlasi product moment dengan taraf signifikasi $5 \%$. Adapun $r_{\text {tabel }}$ penelitian ini adalah 0,24 dan $r_{\text {hitung }}$ yang diperoleh adalah 0,49 . Sehingga nilai hipotesis dalam penelitian ini adalah 0,49>0,24. Maka hipotesis alternatif $\left(\mathrm{H}_{\mathrm{a}}\right)$ : ada hubungan antara keterampilan bertanya guru dengan kemampuan berfikir kritis siswa kelas V SDN Gugus III Cakranegara tahun pembelajaran 2018/2019 diterima. Dengan mengajukan pertanyaan-pertanyaan yang diawali dengan ungkapan-ungkapan seperti "menurut kamu, kirakira..." dan "bagaimana Amerika Serikat mencari," guru diatas sejatinya berusaha memperluas pemikiran siswa melampui memori ingatannya. Kedua siswa diatas mau tidak mau harus menghubungkan informasi yang (dipelajari) sebelumnya dan oleh karenanya mereka harus berfikir pada tingkatan yang lebih tinggi (dalam Jacobsen dkk, 2009).

Pertanyaan-pertanyaan tingkat-tinggi (high-level question) dapat mendorong pemikiran kritis. Untuk melakukan tugas ini, guru harus mengajukan pertanyaan-pertanyaan yang menarik dan menantang yang berhubungan dengan topik dan yang memang dirancang untuk melibatkan pemikiran siswa. Menggunakan pertanyaan-pertanyaan divergen tindak lanjut yang mendorong siswa untuk mengembangkan dan 'menggali' sendiri masalah atau materi pelajaran yang dihadapi. Jelasnya, menggunakan tingkatan-tingkatan proses dalam ranah kognitif untuk merangkai dan mengajukan pertanyaan-pertanyaan yang mendorong usaha-usaha berfikir kritis (Nurfatimah et al., 2020). Hal ini diperdalam dalam penelitian Prasetyaningrum (2014), hasil penelitiannya menunjukkan bahwa adanya keterampilan bertanya guru berpengaruh positif terhadap kemampuan berpikir kritis pada anak kelompok B di TK Al-Hidayah Pakis Tirtosari Surabaya. Artinya jika keterampilan bertanya guru tinggi maka kemampuan berfikir kritis siswa juga tinggi dan sebaliknya.

\section{PENUTUP}

\section{Simpulan}

Keterampilan bertanya sangat penting dikuasai guru, untuk memancing jawaban, komentar, dan pemahaman dari murid-murid dengan maksud untuk menciptakan terjadinya proses intelektual pada siswa, dengan memperhatikan respons atas pertanyaan tersebut. Mengajukan pertanyaan yang mengharuskan siswa untuk menganalisis, mengevaluasi, dan menciptakan informasi adalah tujuan utama dalam mendorong kemampuan-kemampuan berfikir tingkat-tinggi. Berfikir kritis merupakan kemampuan berfikir yang secara cerdas dalam menganalisis, mengevaluasi, dan menciptakan informasi dalam membuat suatu keputusan.

Dari hasil perhitungan menghasilkan Pearson correlation sebesar 0,49 Dengan sig (2tailed) 0,00 dari hasil uji korelasi tersebut menunjukkan bahwa terdapat hubungan yang positif dan signifikan antara keterampilan bertanya guru dengan kemampuan berfikir kritis siswa kelas V gugus 3 Cakranegara tahun pembelajaran 2018/2019, maka hasil yang diperoleh adalah $\mathrm{H}_{\mathrm{a}}$ diterima dan $\mathrm{H}_{\mathrm{o}}$ ditolak. Hasil nilai hipotesis 0,49 termasuk kategori sedang, ini berarti masih ada beberapa faktor dari dalam dan luar diri siswa serta keterampilan dasar mengajar guru lainnya yang memiliki hubungan yang lebih kuat dengan kemampuan berfikir kritis siswa.

\section{Saran}

Beberapa saran yang dapat dijadikan sebagai bahan pertimbangan adalah:

2.1 Bagi kepala sekolah

Mendorong guru untuk mampu terampil dalam keterampilan bertanya guru dengan melakukan pengarahan, pelatihan, dan pembelajaran terstruktur untuk menunjang 
proses belajar mengajar dengan tujuan untuk mengembangkan kemampuan berfikir kritis siswa sesuai tuntutan kurikulum 2013.

2.2 Bagi guru

Pentingnya upaya dari guru untuk mengembangkan keterampilan bertanya guru dasar dan lanjut dengan merencanakan pertanyaan, menggunakan beragam level jenis pertanyaan, menyediakan waktu jeda siswa dalam menjawab pertanyaan, mendengar dengan saksama jawaban siswa, dan memberikan penguatan positif atas jawaban siswa. Sehingga siswa bisa lebih aktif belajar dan merangsang siswa untuk berfikir secara kritis.

2.3 Bagi peneliti lain

Digunakan sebagai pengembangan khasanah keilmuan di dunia pendidikan dalam penelitian selanjutnya. Selain itu membangun komunikasi yang baik dengan kepala sekolah dan guru kelas saat melakukan penelitian di SD Gugus 3 Cakranegara untuk memudahkan penelitian.

\section{DAFTAR PUSTAKA}

Afianti, D., Witono, A. H., \& Jiwandono, I. S. (2020). Identifikasi Kesulitan Guru Dalam Pengelolaan Kelas Di Sdn 7 Woja Kecamatan Woja Kabupaten Dompu. Jurnal Elementaria Edukasia, 3(2), 203-213.

Nurfatimah, Affandi, L. H., \& Jiwandono, I. S. (2020). Analisis Keaktifan Belajar Siswa Kelas Tinggi Di SDN 07 Sila Pada Masa Pandemi Covid-19. Jurnal Ilmiah Profesi Pendidikan, 5(2), 145-154.

Arikunto, Suharsimi; Suhardjono dan Supardi. 2014. Penelitian Tindakan Kelas. Jakarta: PT Bumi Aksara.

Arikunto, Suharsimi. 2006. Dasar Evaluasi Pendidikan (edisi revisi). Jakarta: Bumi Aksara.

Arifin, Zainal. 2017. Evaluasi Pembelajaran (Prinsip, Teknik, dan Prosedur). Bandung: PT Remaja Rosdakarya.

Ahmatika, Deti. 2016. Peningkatan Kemampuan Berfikir Kritis Siswa dengan Pendekatan Inquiry/Discovery. www.fkip-unswagati.ac.id. Vol 3, No 1, p. 395. Online tanggal 11 September 2018.

Crain, William, Theories of Development: Concepts and Applications, $3^{\text {rd }}$ ed., terj. Yudi Santoso, Teori Perkembangan: Konsep dan Aplikasi, cet.1, Yogyakarta: Pustaka Pelajar, 2007.

Djamarah, Syaiful Bahri. 2010. Guru dan Anak Didik dalam Interaksi Edukatif. Jakarta: PTK Rineka Cipta.

Ennis, R. H,. 1991. Critical Thinking: A Streamlined Conception (versi elekronik). Teaching Philasophy, 14 (1), 5-23.

Gunawan, Adi W. 2003. Genius Learning Strategy Petunjuk Praktis untuk Menerapkan Accelarated Learning. Jakarta. Gramedia Pustaka Utama.

Hasibuan, J.J \& Moedjiono. 2009. Proses Belajar Mengajar. Bandung: PT Remaja Rosdakarya.

Jacobsen, David. A; Eggen, Paul dan Kauchak, Donald. 2009. Methods for Teaching:metodemetode pengajaran meningkatkan belajar siswa TK-SMA edisi ke-8. (Diterjemahkan oleh Achad Fawaid dan Khoirul Anam). Yogyakarta: Pustaka Pelajar

Krathwohl. (2002). A Revision of Blomm's Taxonomy: an Overview. Teori into Practice.

Prasetyaningrum, Agil. 2014. Pengaruh Keterampilan Bertanya Guru terhadap Kemampuan Berfikir Kritis Anak Kelompok B di TK Al-Hidayah. www.jurnalmahasiswa.unesa.ac.id. Online tanggal 31 Oktober 2018.

Sugiyono. 2017. Metode Penelitian Kuantitatif, Kualitatif, dan R\&D. Bandung: CV.Alfabeta. 
Sugiyono. 2017. Metode Penelitian Pendidikan (Pendekatan Kuantitatif, Kualitatif, dan R\&D). Bandung: Alfabeta.

Suprijono, Agus. 2016. Model-Model Pembelajaran Emansipatoris. Yogyakarta: Pustaka Pelajar.

Tim Penyusun Panduan Pengajaran Mikro. 2014. Panduan Pengajaran Mikro. Yogyakarta: UNY Press. 